\title{
A sequential double-label 2-deoxyglucose method for measuring regional cerebral metabolism
}

\section{LANCE L. ALTENAU and BERNARD W. AGRANOFF}

The University of Michigan, Neuroscience Laboratory Building, Ann Arbor, Mich. 48109 (U.S.A.)

(Accepted April 20th, 1978)

A radiographic technique involving the use of 2-deoxyglucose (DG) has recently been introduced for the study of regional cerebral metabolism? ${ }^{7}$. Its usefulness is based on the metabolic properties of DG, which bear both striking resemblances and differences to that of the natural substrate, D-glucose. Like D-glucose, DG is transported from the blood into brain cells and is phosphorylated by hexokinase. Unlike glucose6-phosphate (G-6-P), DG-6-P is, however, not a substrate for further metabolism, since the absence of an hydroxyl group in the 2 position precludes further glycolysis via phosphohexoseisomerase or oxidative metabolism via G-6-P dehydrogenase. Labeled DG-6-P is only slowly broken down and is thus metabolically trapped intracellularly, representing a time trace of glucose utilization during the period of active uptake of radiolabeled DG from the blood.

In practice, an animal is injected with a tracer (subpharmacological) dose of $\left[{ }^{14} \mathrm{C}\right] \mathrm{DG}$ while being subjected to an experimental variable. The brain is rapidly removed 30-60 min later and frozen. Cryosections of brain, $20 \mu \mathrm{m}$ thick, are quickly dried on glass slides to minimize diffusion of the $\left[{ }^{14} \mathrm{C}\right] \mathrm{DG}-6-\mathrm{P}$. Contact radioautographs made of these sections with X-ray film possess sufficient resolution to distinguish major brain structures. For example, gray matter is clearly recognizable, on the basis of its greater uptake of the precursor than white matter. If one eye of a rat is covered while the opposite eye is exposed to a light stimulus during the period of active uptake of labeled DG in the blood, the resultant radioautographs reveal an obvious asymmetry with increased grain density over the structures of the contralateral optic radiation ${ }^{8}$.

Sokoloff et al. ${ }^{13}$ have derived an equation by which the optical density of a selected radioautographic region can be related to the rate of glucose utilization. The method requires measurement of blood levels of DG and D-glucose during the period of incorporation, and the use of three rate constants, established for each experimental condition. The validity of the calculations and assumptions has been supported by independent measurements of brain metabolism ${ }^{13}$. Even without quantification, the technique has already enjoyed considerable success as a qualitative tool, the radioautographs often demonstrating striking alterations in regional glucose utilization as a result of differences in the functional state of the various brain areas, including olfactory ${ }^{12}$, visual ${ }^{8}$, tactile ${ }^{3,6}$ and auditory stimulation ${ }^{14}$. 
We demonstrate here the application of a recently proposed sequential doublelabel DG procedure for the measurement of selective changes in regional cerebral metabolism ${ }^{1}$. The experimental animal is injected with $\left[{ }^{3} \mathrm{H}\right] \mathrm{DG}$ during a control' period, followed $1-3 \mathrm{~h}$ later by a second injection, this time with $\left[{ }^{14} \mathrm{C}\right] \mathrm{DG}$, while the experimental variable (e.g. visual, auditory or tactile stimulation, etc.) is being imposed. Thirty to $60 \mathrm{~min}$ following the second radioisotope injection, the brain is removed and frozen. Alternating 20 and $100 \mu \mathrm{m}$ cryosections are then made. The $20 \mu \mathrm{m}$ sections arc used for radioautography, and reveal only ${ }^{14} \mathrm{C}$ distribution, since the film is insensitive to ${ }^{3} \mathrm{H}$ under the conditions used. The radioautograph serves as a template for the sampling of specific regions of the adjacent thick section by means of a punch sampling technique ${ }^{10}$. Brain plugs, 200-1000 $\mu \mathrm{m}$ in diameter, are analyzed for radioactivity, from which ${ }^{14} \mathrm{C} /{ }^{3} \mathrm{H}$ ratios are calculated. The ${ }^{3} \mathrm{H}$ content of the sample provides a baseline level, while the ${ }^{14} \mathrm{C}$ present indicates, a relative increase or decrease in glucose metabolism in a given brain region during the second incorporation period.

While the interval between the second injection and killing can be brief, it is desirable that the ${ }^{14} \mathrm{C}$ level in brain shall have crested (Fig. 1). It has been experimentally

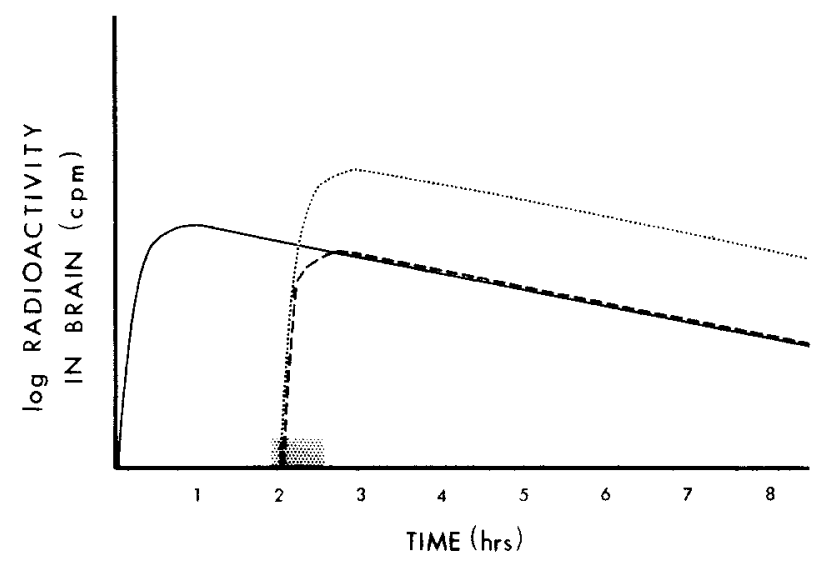

Fig. 1. Diagramatic representation of the principle of the sequential double-label DG method. The solid line (-) represents ${ }^{3} \mathrm{H}$ in the brain following the initial (control) injection of [ $\left.{ }^{3} \mathrm{H}\right] \mathrm{DG}$. Within a few minutes, most of the radioactivity in the brain is in the form of [ $\left.{ }^{3} \mathrm{H}\right] \mathrm{DG}-6-\mathrm{P}$. The dotted line $(\ldots \ldots \ldots)$ and dashed line $(--)$ represent ${ }^{14} \mathrm{C}$ in stimulated and unstimulated brain, respectively, following a second injection with [ $\left.{ }^{14} \mathrm{C}\right] \mathrm{DG}$, while the experimental variable is imposed (shaded area). In the illustrated example we have attempted to achieve $a^{14} \mathrm{C} \mathrm{cpm} /{ }^{3} \mathrm{H} \mathrm{cpm}$ ratio of 1.0 in unstimulated brain regions by injecting an amount of $\left[{ }^{14} \mathrm{C}\right] \mathrm{DG}$ determined as follows:

$\mathrm{B}=\mathrm{E} \cdot \frac{\mathrm{A}}{\operatorname{antilog}[.301(\mathrm{t} / \mathrm{h})]}$.

$\mathrm{B}$ is the $\left[{ }^{14} \mathrm{C}\right] \mathrm{DG}$ in $\mu \mathrm{Ci}$ to be injected at time $\mathrm{t}$, the interval in hours following the initial injection of $A \mu \mathrm{Ci}$ of $\left[{ }^{3} \mathrm{H}\right] \mathrm{DG} ; \mathrm{h}$ is the estimated half-life in hours of DG-6-P in the brain region sampled, while $\mathrm{E}$ is the ratio:

$$
\frac{\text { counting efficiency of }{ }^{3} \mathrm{H}}{\text { counting efficiency of }{ }^{14} \mathrm{C} \text {. }}
$$

Thus, if the counting efficiency for ${ }^{3} \mathrm{H}$ is $18 \%$ and for ${ }^{14} \mathrm{C}$ is $63 \%$, and the estimated half-life of DG-6-P is $8 \mathrm{~h}$, an injection of $125 \mu \mathrm{Ci}$ of $\left[{ }^{3} \mathrm{H}\right] \mathrm{DG}$ followed $2 \mathrm{~h}$ later by an injection of $30 \mu \mathrm{Ci}$ of $\left[{ }^{14} \mathrm{C}\right] \mathrm{DG}$ should produce a ${ }^{1.4} \mathrm{C} /{ }^{3} \mathrm{H}$ ratio of 1.0 , at times after the ${ }^{14} \mathrm{C}$ radioactivity in brain had crested (see text). 

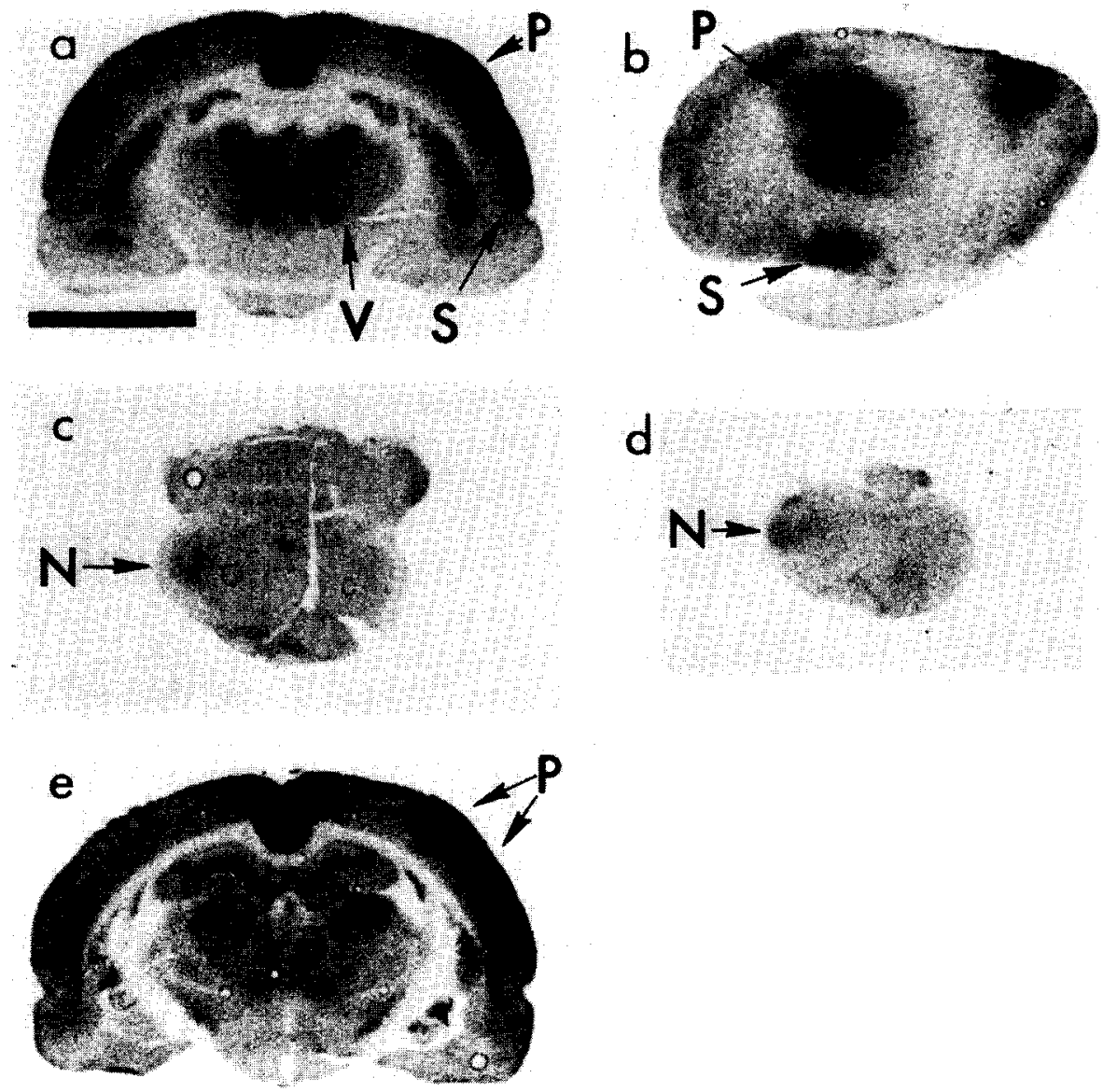

Fig. 2. Radioautographs of brains of rats that had undergone unilateral vibrissal stimulation. Albino rats $(200-250 \mathrm{~g})$ were anesthetized with ketamine throughout the experiment. [G- ${ }^{3} \mathrm{H}$ ]DG $1 \mathrm{mCi} / \mathrm{kg}$ (New England Nuclear, $9.26 \mathrm{Ci} / \mathrm{mmole}$ ) was rapidly infused by means of a small bore catheter in the jugular vein. One hour later the left infraorbital nerve, major branch of the maxillary division of the trigeminal nerve innervating the vibrissae, was exposed. Two hours after the initial pulse, the infraorbital nerve or selected branches were stimulated with a bipolar electrode $(0.4-2 \mathrm{~V}, 10 \mathrm{msec}$ duration, $5 \mathrm{~Hz}$ ) for $5 \mathrm{~min}$ prior to and for $30 \mathrm{~min}$ following an infusion of $\left[1-{ }^{14} \mathrm{C}\right] \mathrm{DG}, 200 \mu \mathrm{Ci} / \mathrm{kg}$ (New England Nuclear, $52.6 \mathrm{mCi} / \mathrm{mmole}$ ). Forty-five min following the second infusion, the animals were decapitated and the brains rapidly removed and frozen in isopentane cooled to $-60^{\circ} \mathrm{C}$ with dry ice. In alternate animals the brain stem and each hemicortex were separated from the remainder of the brain and the latter was flattened between Teflon sheets, following which the samples were frozen separately as described above, and stored at $-70^{\circ} \mathrm{C}$. Coronal cryosections of the whole brain and brain stems, and tangential sections of the hemicortices were obtained, alternating $20 \mu \mathrm{m}$ and $100 \mu \mathrm{m}$ in thickness. The $20 \mu \mathrm{m}$ sections were dried quickly on a hot plate and used to make radioautographs ${ }^{7}$; the $100 \mu \mathrm{m}$ sections were stored at $-70{ }^{\circ} \mathrm{C}$. The radioautographs represent ${ }^{14} \mathrm{C}$, but not ${ }^{3} \mathrm{H}$, distributions. They were subsequently used as templates for punch sampling of the adjacent $100 \mu \mathrm{m}$ thick sections. a: coronal section. An area of increased density is seen in cortex contralateral to the side of vibrissal stimulation, indicating increased glucose utilization in the primary sensory area (P) for the vibrissae, and probably in the secondary sensory area (S); ventrobasilar complex (V) of the contralateral thalamus. $b$ : tangential section of hemicortex contralateral to the side of stimulation, showing $P$ and $S$. $\mathrm{c}$ : upper, and $\mathrm{d}$ : lower brain stem, showing increased density in the trigeminal nucleus and tract (N) ipsilateral to the stimulated side. When anatomically distant (most dorsal and ventral) nerve bundles were stimulated, the radioautograph (e) contained two separate $P$ areas of increased density indicating partial resolution of vibrissal barrel fields ${ }^{17}$. Bar, $5 \mathrm{~mm}$. 
determined that DG-6-P is slowly lost from the brain by first-order decay. The 1 in gray matter is estimated to be approximately $7.7 \mathrm{~h}$, while an average value ${ }^{13}$ for white matter is $9.8 \mathrm{~h}$. Once the $\left[{ }^{14} \mathrm{C}\right] \mathrm{DG}-6-\mathrm{P}$ is brain has begun to fall, the ${ }^{1{ }^{1} \mathrm{C} /{ }^{3} \mathrm{H} \text { ratio }}$ should remain constant, and be relatively insensitive to the exact time of sampling. even though the amount of radioactivity in each isotopic for $\mathrm{m}$ will continue to decrease. If the experimental variable is maintained during the entire period of $\left[{ }^{4} \mathrm{C}\right] \mathrm{DG}$ incorporation, there may be some continued enhancement of labeling of ${ }^{14} \mathrm{C}$, although this could be offset slightly by a further incorporation of residual free $\left[{ }^{3} \mathrm{H}\right] \mathrm{DG}$.

In order to establish the practicability of the sequential double-label DG technique, we elected to study alterations of regional cerebral glucose metabolism associated with unilateral stimulation of the sensory nerves from the vibrissae. The rat's whiskers are primarily involved with contactual exploration of the immediate environment ${ }^{15}$, and the importance of their somatic input is readily evidenced by the work of previous investigators. These studies have indicated, by means of electrophysiological and cytoarchitectural techniques, a comparatively large population of cells activated by individual vibrissae in the trigeminal nucleus ${ }^{9}$, the ventrobasilar complex of the thalamus ${ }^{4,2}$ and, in particular, the somatosensory cortex ${ }^{5,16,17}$, where individual 'barrels' represent each vibrissa. Initial studies with [ $\left.{ }^{14} \mathrm{C}\right] \mathrm{DG}$ radioautographs (Fig. 2) indicated that increased uptake in a discrete brain area could be generated by stimulation of mystacial nerve branches, in agreement with recent preliminary reports of DG radioautography following direct stimulation of vibrissae ${ }^{3,6}$. This experimental preparation then served as a basis for further studies with the sequential double-label procedure. Fig. 3a illustrates the removal of plugs of tissue from $100 \mu \mathrm{m}$ thick sections following location of the area of increased cerebral metabolism from adjacent $20 \mu \mathrm{m}$ thick sections. Using this method, we noted an increase in glucose utilization of $35-45^{\circ}$ 。 in cortical regions representing the stimulated vibrissae (Table I).

The sequential double-label DG technique appears to offer several potential advantages for studies of brain metabolism. Unlike the radioautographic method, it does not require determination of rate constants for each experimental condition. It does not necessitate monitoring of plasma glucose or DG levels, but does assume that the two injections produce similar plasma curves and that the glucose level is the same under each condition. The sequential double-label method does not yield absolute values of brain glucose metabolism, but rather an accurate ratio of relative rates between brain regions. If the physiological variable produces a brain asymmetry, as is the case in the present experiment, ratios can be compared between the affected region and the corresponding contralateral region. The sequential double-label method may be particularly effective, however, in instances where no asymmetry in the radioautographic pattern is produced, in which case the various stimulated brain regions will nevertheless be demonstrable by their higher ${ }^{14} \mathrm{C} /{ }^{3} \mathrm{H}$ ratios when compared to other, contiguous or remote, unstimulated brain regions. Also, while the microheterogeneity of brain structure is a general problem for regional brain studies, sampling errors are minimized with the sequential double-label procedure, since the first injection provides an internal control for each brain sample. Slight differences in the thickness of the section or the size of brain plugs removed will thus not affect the accuracy of the method. 


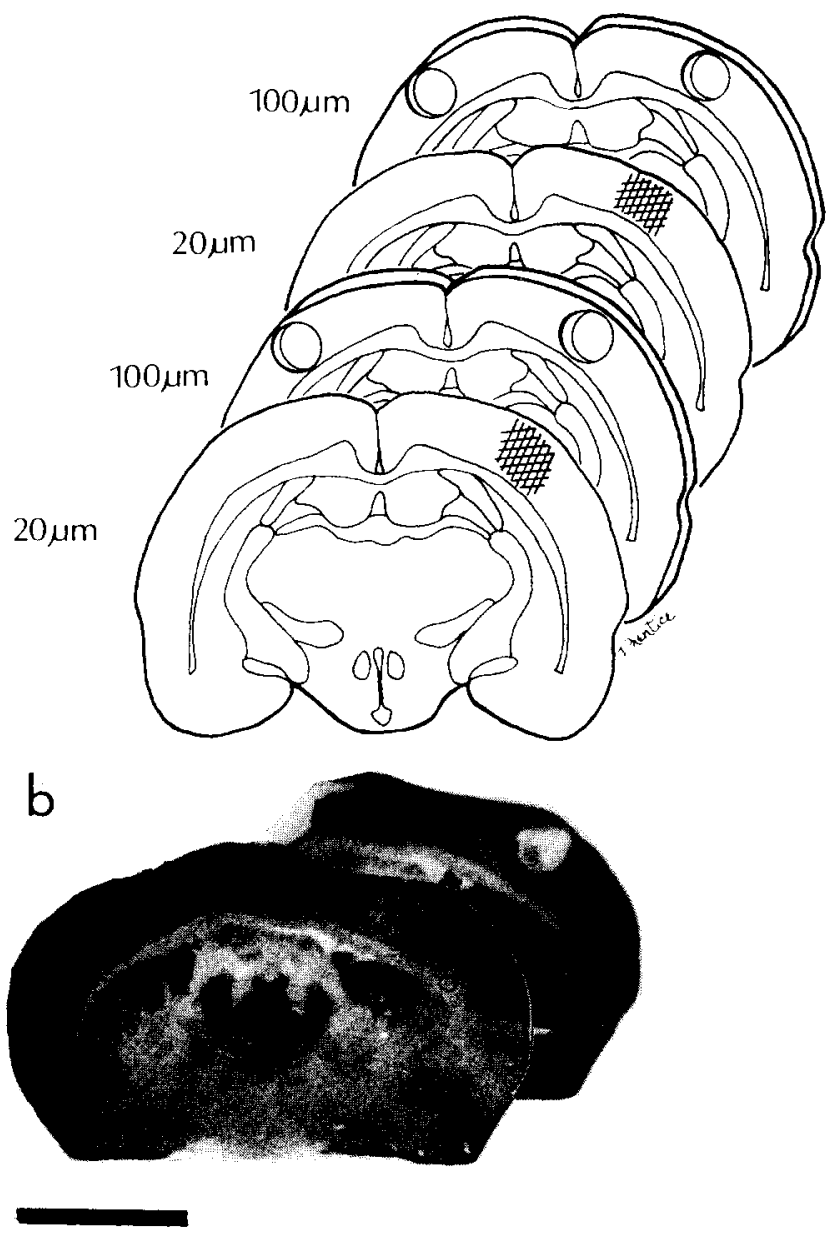

a

Fig. 3. a: diagram of punch sampling procedure. Radioautographs of $20 \mu \mathrm{m}$ sections serve as guides for punch sampling of adjacent $100 \mu \mathrm{m}$ sections for determination of ${ }^{14} \mathrm{C} /{ }^{3} \mathrm{H}$ ratios in appropriate experimental and control regions. b: radioautograph from $20 \mu \mathrm{m}$ coronal brain section following unilateral vibrissal stimulation used for localization, and from adjacent $100 \mu \mathrm{m}$ section (upper right) following punch sampling of stimulated region. Bar, $5 \mathrm{~mm}$.

Since the brain area sampled can be quite small, long counting times may be required, as can be seen in the present study. The method imposes constraints on the interval between the two injections and the time of termination of the experiment. If the two injections are close in time, the possibility arises that sensitivity will be decreased. If they are far apart, the rate of loss of radioactivity may become important. At present, the possible roles of dephosphorylation and rephosphorylation within the brain during this period is not well understood. It is conceivable that regions whose metabolism is relatively high can phosphorylate not only blood DG, but also DG which has diffused from neighboring cells following dephosphorylation.

Possible applications of the sequential double-label method to human brain deoxyglucose studies remain for the future. Thus far, human brain imaging has been 
TABLE 1

Per cent change in ${ }^{14} \mathrm{C} /{ }^{3} \mathrm{H}$ ratio of cerebral cortex of rat following unilateral stimulation of whistisat nertes

The brain plugs removed from the cortex of rats undergoing vibrissal stimulation were $850 \mu \mathrm{m}$ in diameter and $100 \mu \mathrm{m}$ thick. The cortical samples were selected following localization in contact radioautographs made from the adjacent $20 \mu \mathrm{m}$ sections as described in Fig. 2 and the text. Each brain plug was counted in a minivial with $0.3 \mathrm{ml}\left(\mathrm{H}_{2} \mathrm{O}\right.$ and $4 \mathrm{ml}$ Triton scintillant for a minimum of 2000 counts in each channel. In Experiment 1, the rat received $125 \mu \mathrm{Ci}$ of $\left[{ }^{3} \mathrm{H}\right] \mathrm{DG}$, followed $2 \mathrm{~h}$ later by $30 \mu \mathrm{Ci}$ of $\left[{ }^{14} \mathrm{C}\right] \mathrm{DG}$ as per Fig. 1. The ${ }^{14} \mathrm{C} /{ }^{3} \mathrm{H}$ ratio was higher than 1.0. This is attributed to a somewhat lower than expected ${ }^{3} \mathrm{H}$ counting efficiency, and possibly a shorter half-life of DG-6-P than $8 \mathrm{~h}$ in the regions. Nevertheless the stimulated region was clearly demonstrable. In Experiment 2 the rat received 200 $\mu \mathrm{Ci}$ of $\left[{ }^{3} \mathrm{H}\right] \mathrm{DG}$ followed $2 \mathrm{~h}$ later by $40 \mu \mathrm{Ci}$ of $\left[{ }^{14} \mathrm{C}\right] \mathrm{DG}$, resulting in a ${ }^{14} \mathrm{C}_{i}{ }^{3} \mathrm{H}$ ratio closer to $1.0 \mathrm{in}$ the unstimulated regions. The differences between the unstimulated and stimulated ratios were significant to $P<0.005$.

\begin{tabular}{|c|c|c|c|c|c|c|c|c|c|}
\hline & & \multicolumn{4}{|c|}{ Unstimulated (ipsilateral) cortex } & \multicolumn{4}{|c|}{ Stimulated (contraloteral) cortex } \\
\hline & & ${ }^{3} H$ & ${ }^{14} \mathrm{C}$ & ${ }^{14} \mathrm{C}^{3} \mathrm{H}$ & oChan- & ${ }^{3} H$ & ${ }^{14} \mathrm{C}$ & ${ }_{1 \mathrm{CH} H}$ & "Chan- \\
\hline & & \multicolumn{2}{|l|}{$c p m^{*}$} & & $g e^{* *}$ & \multicolumn{2}{|l|}{$\left(p n^{*}\right.$} & & $g c^{\prime * * *}$ \\
\hline \multicolumn{10}{|c|}{ Experiment I } \\
\hline \multirow[t]{4}{*}{ Sample } & 29 & 49.2 & 65.9 & 1.34 & -1 & 50.1 & 95.7 & 1.91 & 40 \\
\hline & 30 & 82.9 & 112.5 & 1.36 & 0 & 68.8 & 137.9 & 2.00 & 47 \\
\hline & 31 & 56.4 & 78.8 & 1.40 & +3 & 94.7 & 178.8 & 1.89 & 39 \\
\hline & 32 & 42.3 & 56.8 & 1.34 & -1 & 83.9 & 162.7 & 1.94 & +43 \\
\hline \multicolumn{10}{|c|}{ Experiment 2} \\
\hline \multirow[t]{4}{*}{ Sample } & 37 & 97.2 & 94.9 & 0.97 & +5 & 108.0 & 154.9 & 1.43 & +54 \\
\hline & 38 & 40.7 & 34.6 & 0.85 & -8 & 65.7 & 87.5 & 1.33 & 43 \\
\hline & 39 & 56.7 & 53.9 & 0.95 & 2 & 61.5 & 70.4 & 1.14 & +23 \\
\hline & 40 & 62.6 & 58.6 & 0.94 & -1 & 85.2 & 103.9 & 1.22 & 31 \\
\hline
\end{tabular}

* cpm corrected for channel spillover and for background.

** Expressed as percentage of average unstimulated ${ }^{14} \mathrm{C} / 3 \mathrm{H}$ ratio.

successful with $\mathrm{F}^{18}$-DG, a positron emitter ${ }^{11}$. In this regard, the eventual availability of gamma-emitting analogs of brain substrates with discriminable spectral emission properties could prove useful for the clinical application of a sequential double-label approach.

This research was supported by Grant NS 13743 of the National Institutes of Health. L.L.A. was supported in part by The Division of Neurosurgery, University of Michigan.

1 Agranoff, B. W. and Altenau, L. L., A sequential double-label method for the measurement of radioactive 2-deoxyglucose phosphate distribution in the brain, Proc. int. Soc. Neurochem., 6 (1977) 513.

2 Davidson, N., The projection of afferent pathways on the thalamus of the rat, J. comp. Neurol., 124 (1965) 377-390.

3 Durham, D. and Woolsey, T. A., Barrels and columnar cortical organization: evidence from 2 deoxyglucose (2-DG) experiments, Brain Research, 137 (1977) 169-174.

4 Emmers, R., Organization of the first and the second somesthetic regions (SI and SII) in the rat thalamus, J. comp. Neurol., 124 (1965) 215-228. 
5 Hall, R. D. and Lindholm, E. P., Organization of motor and somatosensory neocortex in the albino rat, Brain Research, 55 (1974) 23-28.

6 Hard, P. J., Miselis, R. R. and Reivich, M., A [ $\left.{ }^{14} \mathrm{C}\right] 2$-deoxyglucose metabolic mapping study of the rat posteromedial barrel subfield, Seventh Ann. Meet. Soc. Neurosci. Abstr. (1977) 483.

7 Kennedy, C., Des Rosiers, M. H., Jehle, J. W., Reivich, M., Sharpe, F. and Sokoloff, L., Mapping of functional neural pathways by autoradiographic survey of local metabolic rate with $\left[{ }^{14} \mathrm{C}\right]$ deoxyglucose, Science, 187 (1975) 850-853.

8 Kennedy, C., Des Rosiers, M. H., Sakurada, O., Shinohara, M., Reivich, M., Jehle, J. W. and Sokoloff, L., Metabolic mapping of the primary visual system of the monkey by means of the autoradiographic $\left[{ }^{14} \mathrm{C}\right]$ deoxyglucose technique, Proc. nat. Acad. Sci. (Wash.), 73 (1976) 42304234.

9 Nord, S. G., Somatotopic organization in the spinal trigeminal nucleus, the dorsal column nuclei and related structures in the rat, J. comp. Neurol., 130 (1976) 343-356.

10 Palkovits, M., Isolated removal of hypothalamic or other brain nuclei of the rat, Brain Research, 59 (1973) $449-450$.

11 Reivich, M., Neuroanatomical functional mapping by the radioactive 2-DG method. In F. Plum, A. Gjedde and F. E. Samson (Eds.), Neurosci. Res. Program Bull., Vol. 14, 1976, pp. 502-504.

12 Sharp, F. R., Kauer, J. S. and Shepherd, G. M., Local sites of activity-related glucose metabolism in rat olfactory bulb during olfactory stimulation, Brcin Research, 98 (1975) 596-600.

13 Sokoloff, L., Reivich, M., Kennedy, C., Des Rosiers, M. H., Patlak, C. S., Pettigrew, K. D., Sukurada, O. and Shinohara, H., The $\left[{ }^{14} \mathrm{C}\right]$ deoxyglucose method for the measurement of local cerebral glucose utilization: theory, procedure, and normal values in the conscious and anesthetized albino rat, J. Neurochem., 28 (1977) 897-916.

14 Sokoloff, L. J., Relation between physiological function and energy metabolism in the central nervous system, Neurochemistry, 29 (1977) 13-26.

15 Vincent, S. B., The function of the vibrissae in the behavior of the white rat, Behav. Monogr., 1 (1912) $1-85$.

16 Welker, C., Microelectrode delineation of the fine grain somatotopic organization of the Sm I cerebral neocortex in albino rat, Brain Research, 26 (1971) 259-275.

17 Woolsey, T. A. and Von Der Loos, H., The structural organization of layer IV in the somatosensory region (SI) of the mouse cerebral cortex, Brain Research, 17 (1970) 205-242.

Note added in proof. Brain half-life measurements have indeed indicated a significant fraction that decays with $\mathrm{t}_{1}$ less than $2 \mathrm{~h}$, in addition to the longer-lived $(\approx 8 \mathrm{~h})$ component. 